Vol. 1 No. 1, February 2022

e- ISSN 2828-0601, p-ISSN 2828 - 0695

Available online at:

Journal of Classroom

Action Research

https://journal.eltaorganization.org/index.php/jcar

\title{
Improving Students ability in writing Recount text by using Topical Approach at second grade of junior high school
}

\author{
Agnes Wiana Situmorang ${ }^{1}$, Himpun Panggabean ${ }^{2}$ \\ Universitas Methodist Indonesia Medan \\ agnessitumorang369@gmail.com ${ }^{1}$ \\ himpang_25@yahoo.com ${ }^{2}$
}

\begin{abstract}
This study is about the improving writing recount text by using topical approach. This objective of this research is to find out whether the use of topical approach improves the students' skill in writing recount text or not. The subject of this study was one class of the grade. Ten students of SMPN 28 Medan Johor which consisted of 30 students. The action research was conducted of july 2018. The quantitative data were taken from writing test as the instrument to find out students score. The qualitative data were taken from observation sheet, questionnaire, interview and diary notes and obseervation sheet describe the improvement of students' skill in writing recount text was mostly improved in every test. The observation sheet and diary notes showed that the students were interested in the teaching learning process. These finding show thatthere was an improvement on the students'skill in writing recount text by using topical approach that was supported by the result, the mean score post test cycle I $(75,06)$ was better than mean score pre test $(57,43)$ and the mean score of post test cycle II $(82,03)$ was better than the mean score of post test cycle I. There were also positive changes in students' behavior in learning English. During the action, the students paidgood participation to the lesson. The students were more active in joining the processof teaching and learning. Therefore, it canbe concluded that topical approach can improve the students' skill in writing recount text.
\end{abstract}

Keyword : recount text, topical approac.

\section{Introduction}

This objective of this research is to find out whether the use of topical approach improves the students' skill in writing recount text or not. The subject of this study was one class of the grade. Ten students of SMPN 28 Medan Johor which consisted of 30 students. The action research was conducted of july 2018. The quantitative data were taken from writing test as the instrument to find out students score. The qualitative data were taken from observation sheet, questionnaire, interview and diary notes and obseervation sheet describe the improvement of students' skill in writing recount text was mostly improved in every test. The observation sheet and diary notes showed that the students were interested in the teaching learning process. These finding show thatthere was an improvement on the students'skill in writing recount text by using topical approach that was supported by the result, the mean score post test cycle I $(75,06)$ was better than mean score pre test $(57,43)$ and the mean score of post test cycle II $(82,03)$ was better than the mean score of post test cycle I. There were also positive changes in students' behavior in learning English. During the action, the students paidgood participation to the lesson. The students were more active in joining 
the processof teaching and learning. Therefore, it canbe concluded that topical approach can improve the students' skill in writing recount text.

Based on the formulation of the problem above, the objective of the study is to find out whether application of topical approach can improve student writing ability especially in writing recount text.

Theoritically : That is the finding of the study is expected to give evidence about the result of using topical approach in students' writing recount text.

Practically:

1. For the English Teacher to provide recommendation in topical approach for teaching writing recount text.

2. For the student to give them in information of writing recount text which can increase students writing recount text.

3. For the other researcher to provide reference in conducting similar research study abount writing.

Harmer (2004:33) says that "writing is frequently useful as preparation for some other activities, in particular when students write sentences as a preamble to discussion activities". This gives students time to think up ideas rather than having to come up with instant fluent opinions, something that many, especially at lower levels, find difficult and awkward. The writer concludes the writing is one of general English skill which produced a written English text.

Brown (2001:335) says that written language is simply the graphic representation of spoken language and that written perfomance is much like oral perfomance, the only different lies in graphic for writing instead of auditory for speaking. So writing is closely related to speaking not only in such item of content, organization of ideas, and vocabulary but also the relationship og the ideas or the coherent with the other sentence. From some definition above, it can be concluded that writing is a system of human communication which represent a symbol. By writing, we can share our idea, feeling, or anything that exist in our mind. Writing prosecuts student to focus on generating idea, organizing coherently, revising it into good composition, using discourse markers and rhetorical convention cohesively, and editing text for appropriate grammar. Therefore, student who want to be able to write a good writing, they must learn to write regulary.

\section{Micro and Macro Skill of Writing}

In writing, there are some aspects that have to be considered. Brown (2004:221) has summarized all those into main skill, they are the micro and macroskills of writing. They are needed to develop the effective writing. Those skills are described as follow:

Microskills :

1. Produce graphemes and orthographic patterns of English.

2. Produce writing at an efficient rate of speed to suit the purpose

3. Produce an acceptable core of words and use appropriate word order patterns

4. Use acceptable grammartical system (e.g., tense, agreement, pluralization), patterns and rules.

5. Express a particular meaning in different grammatical forms.

6. Use cohesive devices in writing discourse

Macroskills:

1. Use the rtetorical forms and conventions of written discourse

2. Appropriately accomplish the communicative functions of written texts according to form and purpose. 
3. Convey links and connections between events, and communicative such relations as main idea supporting idea, new information, given information, generalization, and exemplification.

4. Distinguish between literal and implied meanings of writing

5. Correctly convey culturally specific references in the context of the written text

6. Develop and use a battery of writing strategies,such as accuratelly assesing audience interpretation, using prewriting devices,writing with fluencyin the first drafts, using paraphrases and synonyms,soliciting peer, and instrucor feedback, and using feedback for revising and editing.

In conclusion, the microskill covers about the mechanical of writingand and at the level of word, such as cohesive devices, past verb, etc. Meanwhile the macroskill covers wider areas of writing, such as the form and the communicative purpose of a written text, main idea, and supporting idea, the literal and implied meaning writing, etc .

\section{Process of Writing}

Process writing is a never one step action. Harmer (2001:4) states that writing as one of productive skill needs a process.this process sues writer in sequence stages. Harmer states that the writing process is the stages that a writer goes through in order to produce something (a written text) before to be a final draft. There are four processes of writing.

\section{Planning}

Planning is the first step in writing. The writer try and decide what they are going to say in their writing. For some writers this may involve making detailed notes. When planning, writers have to think about three main issues, they are: in the first place they have to consider the purpose of their writing since this will influence (among ather things) not only the type of text they wish to produced, but also the language used, and the information choose to include. Secondly, the writers also think of the audience they are writing for, since this will influence not only the shape of the writing (how it is laid out, how the paragraphs are structured). But also the choice of language whether, for example, it is formal or informal in language. Thirdly, writers have to consider the content structure of the piece that is, how best to sequence the facts, ideas, or arguments which writers decided to include.

\section{Drafting}

We can refer to the first version of a piece of writing as a draft. This first go at a text is often done on the assumption that it will be amended later.

\section{Editing (reflecting and revising)}

Once writers have produced a draft they then, usually, read through what the have written to see where it works and where it doesn't. Reflecting and revising are aften helped by other by other readers (or editors) who comment and make suggestion. It will help the author to make appropriate revisions.

\section{Final version}

After editing their draft, the writers make the changes that consider being necessary for their final version. In final version is ready to send the written text to its intended audience. 


\section{The Purpose of Writing}

When we think of writers, we normally think of those who craft creative fiction, short stories, poems, novels, maybe even dramas or screenplays. One key to successful writing, however, is the ability to write in multiple forms and for a variety of purposes.

1. The introduction and practice of some form of writing enebles us to provide for different learning styles and needs. Some learners, especially those who do not learn easily through oral practice alone, feel more secure if they are allowed to read and write in the language. For such students, writing is likely to be an aid to retention, if only because they feel more at ease and relaxed.

2. Written work serves to provide the learners with some tangible evidence that they are making progress in the language. It is not likely to be a true index of their attainment, but once again it satisfies a psychological need.

3. Exposure to the foreign language through more than one medium is likely to be more effective than relying on a single medium alone. Writing also provides variety in classroom activities, serving as a break from oral work, and increases the amount of language contact through work that can be set out of class.

4. Writing is often needed for and informal testing. Although in general oral ability should be measured through oral tests, in practice we are often obliged by circumstances, such as the amount of time we have at our disposal and the number of students there are in the class, to use some form of written test. In some cases, of course, a written test may even be appropriate: for example, making notes while listening.

\section{Requirements of Good Writing}

Good writing in any languages involves knowledge the convention of written discourse in culture as well as the ability to choose the precise words that convey the meaning. To write an interesting text and good paragraph, we have to know what a paragraph is. According to Barli (1995:13), "paragraph is a group of sentences which contain relevant information about one idea or central idea.

A good paragraph normally focuses only on one idea that is expressed in the topic sentence. Topic sentence is important to express an idea. Function of the idea is to control the content of paragraph. Idea is the begining of creative process. A paragraph basically consists of three parts : those are introduction, body, and conclusion

\section{Kinds of Genre}

According to Hartono (2005:6), there are twelve types of genre text, they are:

\section{Recount}

Recount is a text which retells events or experiences in the past. Its purpose is either to inform or to entertain the audience. Generic structure of recount is orientation, events, and reorientation.

\section{Narrative}

Narrative is a very precise type of text to tell the activity or past events, which highlight the problematic experience and resolution with the intention of entertaining and often intended to give moral lessons to the reader).

\section{Procedure}

Procedure text is a text that is designed to describe how something is achieved through a sequence of actions or steps.

\section{Explanation}

Explanation is a written English text in which the writer explains the process involved in the workings of natural or sociocultural phenomena. 


\section{Discussion}

Discussion is a written English text in which the writer presents some points of view about an issue.

\section{Report}

A report is a text containing two components that is, general classification and description.

\section{Analitycal Exposition}

Analytical Exposition is an expository text. It is about the truth of a fact of a certain object and exposes it to the reader.

\section{Anecdote}

Anecdote is any written English text in which the writer shares with the others an account of an unusual or amusing incident.

\section{Spoof}

In writing, a spoof is known as a narrative text. It introduces a number is characters. They can be human and non human characters.

\section{Hortatory Exposition}

Hortatory Exposition is a written English text in which the writer persuades the people that something should or should not be the case.

\section{News item}

News item is a text containing three components that is, new worthy events, background events, and sources.

\section{Review}

Review is a kind of genre used to critique an art work or event for a public audience.

\section{Definition of Recount Text}

According to Hartono (2005:6) define recount text is a report or retell of event or activity in the past. It is to inform or to entertain the readers. The meaning of the genres intended is that students are able to understand to concept and they would be able to identify a kind of the texts that the students will have to write.

\section{Type of Recount}

According to Hyland (2004:135), there are three types of recount text :

1. Personal recount : retelling of an activity that the writer or speaker has been personally involve in(e.g. oral anecdote, diary entry).

2. Factual recount : recording the particular of an accident (e.g. report of a science experiment, police report, news report, historical account).

3. Imaginative recount : taking on a imaginary role and giving details of events (e.g. aday in the life of a roman sale; how I invent)

\section{Generic Structure of Recount}

According to Hyland (2004:135), there are three generic stucture of recount text. They are :

1. Orientation : provide the setting and produces participants. It provide information about who, where, and when.

2. Record of events : what happen, present event in temporal sequence. It is usually recount in chronological order. Personal comments and or evaluative remark, which are interprent the throughout the record of event.

3. Re-orientation : optional- closure of events. It is ' rounds off' the sequence of events 


\section{Grammartical Feature of Recount}

Acording to Hyland (2004:135), the common grammatical features of recount text are:

1. Use of nouns and pronouns to identify people, animal, things involve for example Mr.John, My rabbit, etc.

2. Use of action verbsto refer to events( went, climbed,etc)

3. Use of past tense( cried, bought, etc).

4. Use of conjuctions of time connectives to sequence of events ( then, next, ets).

5. Use of adverb and adverbial phrase to indicate place and time ( yesterday, last month, etc)

6. Use of adjective to describe nouns ( smart, beautiful, etc).

Here is the example of recount text :

\section{Our trips to the blue mountain}

Orientation : On Friday we went to the blue mountain. We stayed at Dyan and

Bella's house. It has a big garden with lots of colorful flowers and a tennis court.

Event 1 : On Saturday we saw two sisters and went on the scenic railway. It was scary.Then, Mummy and I went shopping with bella. We went to some antique shops and I tried on some old hats.

Event 2: On Sunday we went on the scenic skyway and it worked. We saw cockatoos having a shower.

Reorientation : In the afternoon we went ho

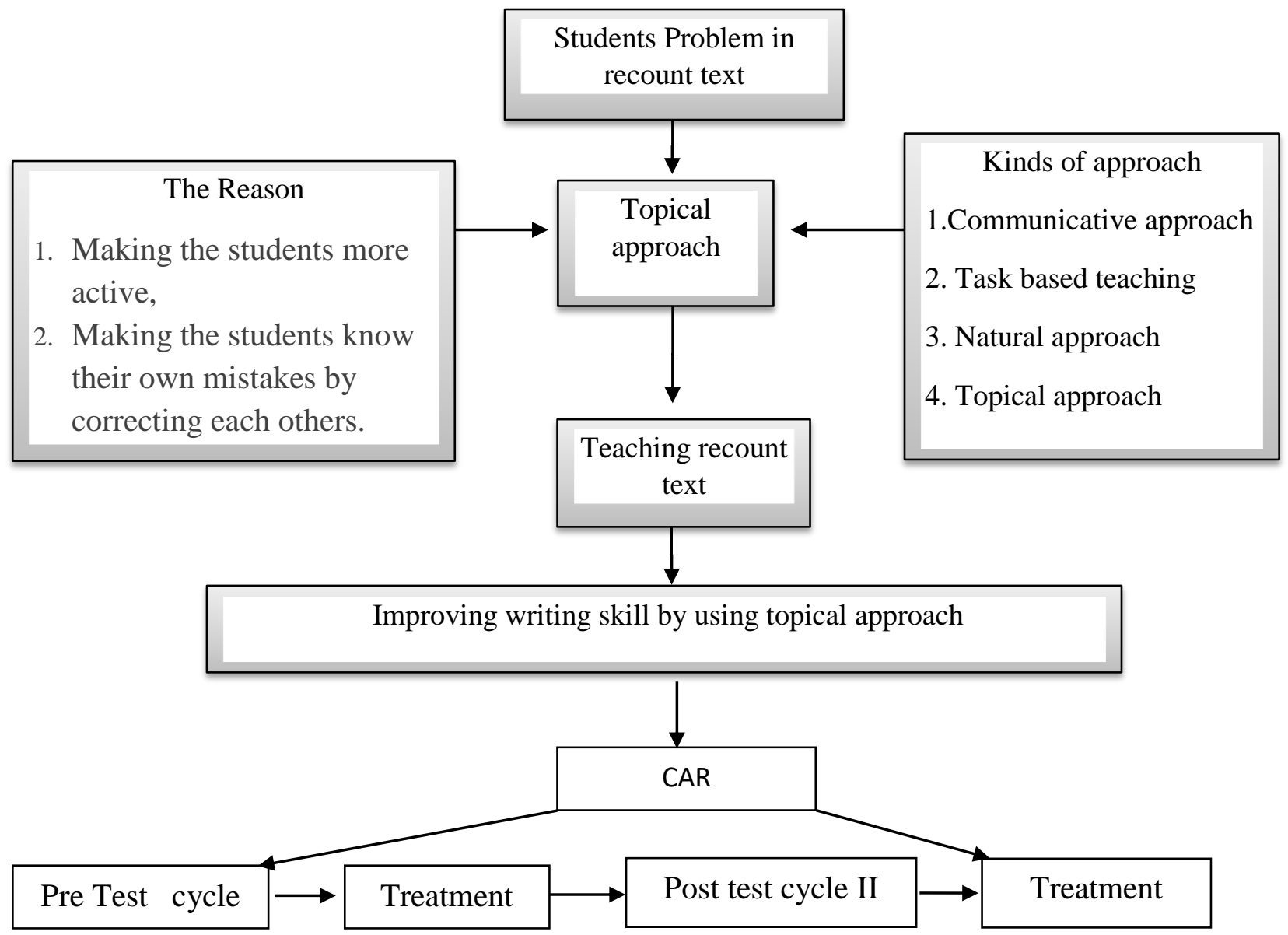

Figure 1 The Conceptual Framework

Published by English Lecturers and Teachers Association (ELTA)

Copyright (C) 2022, authors 


\section{Research Design}

This study would be conduct by using classroom action research. The aim of research is to improve the quality of English teacher perfomance in teaching learning process. According to Arikunto (2010: 130), classroom action research is a study toward activities that are intentionally appear and happen in a class. It includes the use of quantitative and qualitative design in this rasearch. Classroom action research has two cycles, namely: 1) planning, 2) action, 3) observation, and 4) reflection. The reason of using this method is to solve the problem appear in the class under research.

\section{The Population and Sample}

\section{Population}

The population is the students at grade VIII in teaching and learning process of SMPN 28 Medan Johor the academic year of 2018/2019

\section{Sample}

This sample is 30 students to researcher at grade VIII who are in still first semester in the academic year of 2018/2019. The research only need 1 class of 5 class

\section{The Instument of Collecting Data}

The data of the research were quantitative data and qualititative data. The quantitative data were in the form of reading comprehension scores based on a pre-test and a post-test.The qualitative data were in the form of field notes and interview transcripts. The instruments of the research were in the form of reading pre-test and the post-test, observation and interview.

\section{Research Procedure}

The procedure of action research consist of two cycle. In addition, each cycle would be done basd on the plan that has planned before, and this research would be done based on the action research approach. In conducting the action research, there are steps that include, such as; planning action, observation and reflecting.

\section{Planning}

In this step, the writer prepared the instruments such as lesson plan, observation sheet, questionaire sheet, interview sheet, diary notes, and writing test to be applied in teaching and learning process.

\section{Action}

Phase was the implementation of planning. The writer will do everything that she plans. The writer distributed questionaire to fill in by the students. The writer tried to socialize topical approach in teaching learning process. But, before using topical approach , the writer would conduct the first test to find the basic students skill in writing recount text.

\section{Observation}

It would be done together with action in the same time. The purpose was to find out information of action, such as student attitudes, behaviour, activities, and problem during teaching- learning process. While the writer didaction. The writer observed whole teaching learning process in the classroom. In doing observation and evaluation, the writer would be help by the English teacher as the collaborator. The writer would take the data from questionnaire sheet, interview, observation sheet and diary notes which would be used as the basic reflection. 


\section{Reflection}

Reflection was the evaluation of actions that already done before. The reflection recovered the problem that happen in the previous cycle. In this phase, the writer would take the result of observation. The writer would write the strength and weakness on the diary note during the teaching learning process and to keep strength and improve the weakness would be take from questionnaire sheet, interview, observation sheet, and test for the next cycle.

\section{The Teaching Learning Process}

The processof doing the technique will be done in two cycles. The first cycle, consist of four phases namely planning , action ,observation, and reflecting.

\section{Cycle I}

In this cycle, the writer would be observed the situation of conventional laerning process in the class sample, made an oral interview with the student in order to knew their opinion about learning English especially writing activity and identify the student problem in writing activity.

\section{Planning}

Planning is the first step in classroom action research. The activity would be done in the steps of planning as follows:

1. Preparing the lesson.

2. Preparing the instruments for collecting the data such as questionnaire sheet, interview, observation sheet, and diary note.

3. Preparing the test in this cycle.

4. Making pre-test as the instrument to know the student basic skill in writing a recount text before gave the action.

5. Designing of procedure of teaching writing through topical approach

\section{Action}

In the step, the scenario of teaching and learning writing through topical approach design was implemented in the process of teaching and learning in the classroom. There are many activities in actions, they were:

1. The teacher explained the definition of recount text, purpose, generic structure and lexicogrammartical features.

2. The teacher also explained the meaning of topical approach, its advantages, procedure and technique.

3. Teacher gave students a recount text. Then, the teacher asked them to identify the social function, generic structure, grammartical feature of texts and discuss the content of the text by translating the text together.

4. Student would be divided into group consist of five student. The student divided into five person in a group.

5. Teacher asked student to sit in their group but did it individually.

6. The teacher dictated a recount text, and the student listened it.

7. The teacher dictated a recount text or second times and the student listened and took notes the main information of the text. After that, they combined the words and reconstruct the text with correct grammartical.

8. The student present their work.

9. The student gave comments to other groups work

10. The writer asked student opinion about the technique that already applied by writing it in a piece of paper. 


\section{Observation}

In this step, the writer observed the whole process of actions teacher. Student (included behavior the way of student work., cooperation, response, and the situation).

\section{Reflection}

Reflecton was the evaluation of the action that has been done. Reflection would be done after the student already done all of the steps or activities on the class.

The arrangements were:

1. Teacher asked the student to collect their work and gave them score.

2. Next action ( the writer resived plan for the second cycle)

There are five components in writing assesment according to jacob et al scale (weigle, 2002:116) namely:

\section{Content}

Content refers to the students ability to write the ideas and information in the form of logical statement.

Table 1 Content Criteria Assesment

\begin{tabular}{ll}
\hline $30-27$ & $\begin{array}{l}\text { Excellent to very good: knowledgeable, substantive development of } \\
\text { thesis, relevant to assigned the topic. }\end{array}$ \\
\hline $26-22$ & $\begin{array}{l}\text { Good to avarage: some knowledge of subject, adequate range, } \\
\text { limited development of thesis, must be relevant to the topic but lacks } \\
\text { of details. }\end{array}$ \\
\hline $21-17$ & $\begin{array}{l}\text { Fair to poor: limited knowledge of subject, little substances } \\
\text { inadequate development of topic. }\end{array}$ \\
\hline $16-13$ & $\begin{array}{l}\text { Very poor : does not show knowledge of subject, non substantive, } \\
\text { not partinent, not enough to evaluate. }\end{array}$ \\
\hline
\end{tabular}

\section{Organization}

Organization refers to the students' ability to write ideas and information in good logical order. The topic and supporting sentences are clearly stated.

\section{Table 2 Organization Criteria Assesment}

\begin{tabular}{cl}
\hline 20-18 & $\begin{array}{l}\text { Excellent to very good: fluent expression, idea clearly stated/ } \\
\text { supported, well organized. }\end{array}$ \\
\hline $17-14$ & $\begin{array}{l}\text { Good to avarage: some what choppy, loosely organized but main } \\
\text { ideas stand out, limited support logical but incomplete time } \\
\text { sequence. }\end{array}$ \\
\hline $13-10$ & $\begin{array}{l}\text { Fair to poor: non-fluent, an idea confused or disconnected, lacks of } \\
\text { sequencing }\end{array}$ \\
\hline $9-7$ & $\begin{array}{l}\text { Very poor : does not communicate, no organization, not enough to } \\
\text { evaluate }\end{array}$ \\
\hline
\end{tabular}

\section{Vocabulary}

vocabulary refers to students' ability in using word idiom to express ideas logically, and also refers to ability to usethe synonym, prefix, and suffix exactly. 


\section{Table 3 Vocabulary Criteria Assesment}

20-18 Excellent to very good: sophisticated range effective word choice, word and usage from mastery,appropriate register.

17-14 Good to avarage: adequate range, choice, meaning not obscure,occasional errors of word.

13-10 Fair to poor: limited range, frequent error of word/idiom word,usage but meaning confused.

9-7 Very poor : essentially translation, little knowledge vocabulary, not enough to evaluate.

\section{Language Use}

Language use refers to the students' ability in writing sentences simple, complex or compound sentences correctly and logically. It also refers to the ability to use agreement in the sentence and some other words such as nouns, adjectives, verbs, and time signal.

\section{Table 4 Language Use Criteria Assesment}

25-22 Excellent to very good: effective construction, few errors of agreement, tense, number, word order, pronoun, and preposition.

21-18 Good to avarage: simple construction, minor problem, several errors of agreement, meaning seldom obscured

17-11 Fair to poor: mayor problem in simple/ complex construction, frequent error of negation, meaning confused.

10-5 Very poor : virtually no mastery of sentence construction,dominated by errors, does not communicate, not enough to evaluate

5. Mechanics

Table 5 Mechanics Criteria Assesment

\begin{tabular}{cl}
\hline 5 & $\begin{array}{l}\text { Excellent to very good: demonstrates masteryof conventions, few } \\
\text { errors of speelling, punctuation, capitalization,paragraphing. }\end{array}$ \\
\hline 4 & Good to avarage: occasional errors,meaning not obscured. \\
\hline 3 & $\begin{array}{l}\text { Fair to poor: frequent errors of spelling, punctuation capitalization, } \\
\text { paragraphing, poor hand writing, meaning confused. }\end{array}$ \\
\hline 2 & $\begin{array}{l}\text { Very poor : essentially translation, little knowledge vocabulary,not } \\
\text { enough to evaluate. }\end{array}$ \\
\hline
\end{tabular}

The technique of analyzing the data are described as followed:

1. calculating the data from scoring from pre-test and post-test

2. tabulating the score from pre-test and post-test

3. comparing the students data between pre-test and post-test

4. Making the conclusion

$$
X=\frac{\Sigma x}{N} \times 100 \%
$$

\section{The Data Analisis}

In this research, the data were analyzed from quantitative and qualitative data. The quantitative data were taken from the mean of the students in taking writing test. The qualitative data were taken from observation sheet, questionnaire sheet, interview and diary note. This reserch was conducted in one class with 40 samples. It was class of VIII SMPN 28 MEDAN JOHOR. It 
was accomplished in two cycles. Each cycle consisted of four steps of action research ( planning, action, observation, and reflection). The first cycle consisted of three meetings and second cycle consisted of three meetings. So, totally there were six meetings in ths research.

\section{The Quantitative Data}

The quantitative data were taken from the score of writing test. The pre test was given in the first meeting without any treatment to the students, while the test after each cycle were given after the students got some treatments. In pre test, the student generally got some bad scores, but the beginning of first cycle until the end of second cycle, the scores were improved.

Table 6 Student' Mean Scores

\begin{tabular}{ccc}
\hline Tests & Total Score & Mean \\
\hline Pre Test & 1723 & 57,43 \\
Post Test Cycle I & 2250 & 75,06 \\
Post Test Cycle II & 2461 & 82,03 \\
\hline
\end{tabular}

The range of the students score improvement is as followed: There were seven students who got the highest score improvement, they are in the range 31-60( high). There were sixteen students in the range of score improvement 21-30 ( medium). There were seven students in the range of score improvement 11-20 ( low)

Table 7 Range of Score Improvement

\begin{tabular}{clc}
\hline Range of Score Improvement & Students Initial & Total \\
\hline $31-60$ & AR,HR,MAN,MIL,MH,MR,MAW & 7 \\
$21-30$ & AM, CA, DA,FIN,HAC,MJ, MRF, & 16 \\
& MRW,MAR,NF,NK,NS,NW,R,SR,WF & \\
$11-20$ & AA, NA, NAP, RS,RK, RS,SP & 7 \\
\hline
\end{tabular}
as follow:

The percentage oof students who were success in learning during the research could be seen

The number of students who got score $\geq 75$ in pre -test was one students and the number of the students who did the test were 30 students. So, the percentage of students who got score $\geq 75$ was $3.33 \%$.

The percentage of students who were success in learning in post test cycle I: the number of students who got $\geq 75$ were 18 students and the number of students who did the test wew 30 students. So, the percentage of students who got score $\geq 75$ was $60 \%$.

The percentage of students who were success in learning in writing post-test cycle II: the number of students who got $\geq 75$ were 27 students

Table 8 The Percentage of Master Students in Writing Competence

\begin{tabular}{llcc}
\hline Meeting & \multicolumn{3}{c}{ Student who got score up to 75 } \\
\cline { 2 - 4 } & Students' Initial Name & Total & Percentage (\%) \\
\hline Pre Test & WF & 1 & $3,33 \%$ \\
\hline Post Test (cycle I) & CA, DA, FIN, HAC, HR, MIL, \\
& MJ, MRF, MAN, NAP, NP, & $60 \%$ \\
\hline
\end{tabular}

Published by English Lecturers and Teachers Association (ELTA)

Copyright (C) 2022, authors 


\begin{tabular}{lll}
\hline & NK, NS, R,RS RK, SR, WF & \\
\hline Post Test (cycle II) & AM,AR,CA,DA,FIN,HAC,HR, & 27 \\
& MAN, MIL, MJ, MH, IA, MR, & \\
& MRF,MRW,MAR,MAN,NAP, & \\
& NF, NK, NS, NW,R, RS, RK, & \\
& SP, SR,WF & \\
\hline
\end{tabular}

From the result of observation sheet, it can be concluded that teaching learning process by applying Topical Approach run well. The situation of teaching learning process was comfortable. So, Topical Approach created a good environment in teaching learning in which the students became more active in the process writing. They paid attention tothe teacher explanation, could express their ideas in writing, and finally making a good relation with their group and they can write a recount text individually.

From the result questionnaire sheet, it can be found out that topical approach can improve the students' abilities because from the data only some of the students filled in disagree. It means that topical approach was very good for the students.

Based on the interview, the students had problem in learning writing especially recount text. They admitted that they still had low writing skill because they lacked vocabularies and also rarely reviewed the lesson that they have learned. However, after they got the treatment, they said that topical approach helped them in writing recount text.

From the diary notes, it was found that at begining of the research, students had difficulties in writing recount text. They were not interested in learning English especially writing lesson. But they became interested and enjoy English in teaching and learning process after the writer applied topical approach. By applying this technique, they knew how to write a recount text based on the result of their group discussion and individually.

The writer organized all quantitative and qualitative data from all meetings. In every two meetings, the writer conducted writing evaluation. From the first evaluation, it was found that students abilities in writing recount text was still low. They were confused how to write down recount text based on generic structure and language features. Next, the first cycle of CAR was conducted and students were given a treatment of topical approach at the first time. Next, the writer did the second cycle, and the result was better than the first cycle.

The mean of pre test 57, 36 which was very low because the students did not know how to write recount text and one student get score $\geq 75$ so the percentage of students who are success in learning improved writing test $\mathrm{I}$ is $3.33 \%$. After the first cycle was conducted after treated by topical approach, the mean score of writing test in cycle I was 75, 06 and there were nineteen students who got point $\geq 75$ in the first cycle so the percentage of the students who are success in learning improved in writing test II is $60 \%$. The students' mean score in post -test cycle II after treated by topical approach was 82,03 and there were 27 students got score $\geq 75$ so the percentage of the students who were success in learning improved in writing test II is $90 \%$. It can be concluded that the use of topical approach was effective in improving the students' ability in writing recount text.

The writer also analyzed data support this research finding beside the quantitative data( writing evaluation score) the qualitative data were taken from observation sheet, questionnaire sheet, interview sheet, and diary notes. The result of observation showed that the students gave their good attitude and responses during the teaching and learning process. Even though they had problems at first time but they handled their problem and enjoyed their lesson. They became more active and interested in writing. Questionnaire and diary notes showed that the application topical 
approach helped them in writing recount text. All qualitative data supported the research finding which based on the quantitative data.

\section{Disscussion}

The use of topical approach helped the students be easier in learning writing especially in writing recount text. The teacher motivated students to give the best, gave them chances to ask question to the teacher if they found difficulties. This research had proved the effectiveness of topical approach. It can be seen from the students' scores from pre-test in cycle I and post -test in cycle II which continuously increased.

This improvement was not only happened in the mean of students' scores but also their interests and expression which there were improvement. Itcan be seen from questionnaire sheet , observation sheet, interview sheet and diary notes. Most of the students were more active during teaching and learning process.

Based on the result of quantitative and qualitative data during cycle I and II, the writer found that the students made improvement in their skill in writing recount text, and also it was found the teaching learning process run well. It can be concluded that the application of topical approach was sussesful in improving students' abilities in writing recount text.

\section{Conclusions}

Having analyzed the data that have been presented in the previous chapter. The conclusions of the research are:

1. The score increased continuously from the first evaluation to the third evaluation. It can be seen from the improvement of the mean of the students' score namely: the students'mean score in pre test 57,43(3,33\%), it is improved in post-test cycle I become 75,06 (60\%) and the students mean score in post -test cycle II 82,03(90\%).

2. The student average scores in each evaluation kept improving. It can befound that there is a significant improvement on the students' abilities in writing recount text by application of topical approach.

3. The result of observation show that the students give good attitude and responses during the teaching and learning process. From the questinnaire sheet, and diary notes, the students agree that topical approach helps them in writing recount text. It can be concluded that the application of topical approach significantly improves the students abilities in writing recount text.

\section{REFERENCES}

Arikunto, (2010). Prosedur Penelitian : Suatu Pendekatan Praktek. Jakarta: PT.Rineka Cipta.

Arikunto, (2010).Prosedur Penelitian.Jakarta:Rhineka Cipta

Bram, Barli. (1995).Write Well Improving Writing Skills. Yogyakarta : penerbit kanisius.

Brown, Douglass(2001). Teaching by Principle an Interactive Approach to Language Pedagogy. San Francisco : Longman.

Brown, Douglass(2004).Principlesof Language Learningand Teaching. Amazon Company.

Byrne ,Donn.(1979). Teaching Writing Skill. Essex: Longman.

Byrne ,Donn.(2002).Social psychology, USA pearson

Published by English Lecturers and Teachers Association (ELTA)

Copyright (C) 2022, authors 
Ewen, Robert (1998). Personality : A Topical Approach: Theoris, Research, Major Controversies and emerging findings. Amazon Company

Feldman, Robert. (2004) . Life Span Development: A Topical Approach(3rd ed). United state of America: Amazon company.

Harmer, J.(2004). How to Teach Writing .Essex: Longman group, Ltd.

Harmer,J. (2001): Languange Teaching Approach and Method.Longman group, Ltd.

Hartono,Rudi.(2005).Genres of Text. Semarrang: UNNES.

Ken,Hyland.(2004).Genre and Second Language Writing .The United State of America: The University of Michigan Press.

Kern, Richard.(2000).Literacy and Language Teaching.New York:Oxford University Press

Richard and Rodgers (1999). Approaches and Method in Languae Teaching. United State of America. Cambridge Language Teaching Library.

Weigle Sara. 2002. Assessing Writing Language Assesment Series. United Kingdom. Cambridge University Press. 